\title{
5 \\ Magical thinking to dispel fear and uncertainty
}

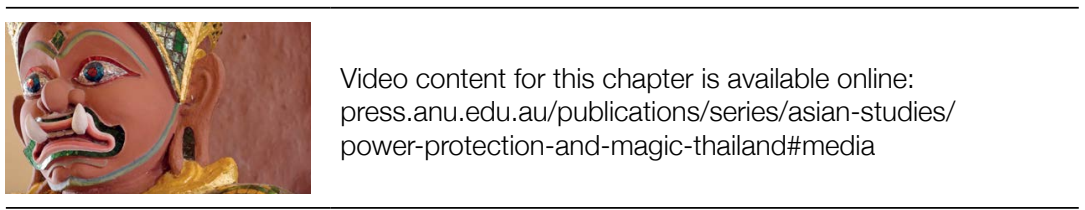

Before the military coup in May 2014, the darker side of magical knowledge such as black magic and curses had been employed by both the Yellow Shirts and the Red Shirts in their bitter political campaigns. When the Yellow Shirts were campaigning for the removal of the Thaksin party from government in late 2008, they broke into the grounds of Government House and vandalised the Brahma shrine there. A Khmer ritual specialist was then engaged to decommission the Brahma image using his supernatural powers-Khmer magic being regarded in Thailand as particularly powerful. A few years later, in March 2010, when the Yellow Shirts were in power, the Red Shirts set up camp in the centre of Bangkok and embarked on a spectacle of bloodletting and bloodspilling described by an American newspaper as one of the 10 most bizarre protests in the history of the world. The Red Shirts donated blood en masse as a sign of their willingness to shed their blood for democracy. A Brahman priest performed curses at the headquarters of the Democrat Party - a ritual aimed at spooking the Abhisit Vejjajiva-led Democrat regime and weakening its hold on government. This brazen act by a ritual specialist who came from nowhere infuriated the capital's established Brahman families, who sought to discredit the upstart priest. All that red blood in digital images on the internet made for great theatrics and became 
a proxy in the war of position in the political field (Nostitz 2010; Cohen 2012). In political warfare, as well as in war to defend the homeland, demonising the enemy can be motivational. In the preparation of soldiers for battle, dehumanising the enemy leads men to do the unthinkable and take human life (Nidhi 2012: 11-12).

Warriors need the protection of armour as well as technologies of invulnerability that are as important to survival as wielding a knife or carrying a gun. Thai soldiers in the expeditionary force sent to Vietnam during the Second Indochina War (1959-75) returned home convinced that the protective devices they wore around their necks were not only efficacious, but also superior to any other form of spiritual protection available to allied or enemy troops. The soldiers were young and the young think they will live forever, enabling them to overlook the reality of their own vulnerability. The soldiers appealed to the protective devices just in case and, in fact, would not fight without their amulets, as the American command discovered when it confiscated the objects for security reasons (Ruth 2012: 129, 145). Some talismans were distinctly Buddhist, others less so. In Thailand and other countries, Buddhism and magic overlap in offering protection, which is not only spiritual and emotional, but also social, in keeping an individual and the community safe from harm. Social protection takes the form of guardianship, custodianship, patronage and refuge and a place of safety. The taking of refuge is the act that defines a Buddhist (Skilling 1992: 12).

During his policing exploits in which he called upon his knowledge of the dark arts, Khun Phan earned a reputation as a man who knew about the technologies of protection. When he retired in 1964 as a police major general in command of the Nakhon Provincial Circle, his exploits in apprehending bandits, criminals and separatists came to an end. To celebrate his retirement, he collaborated with another retiring policeman in casting amulets for distribution to police comrades, soldiers and laypeople; amulets were also presented to King Bhumibol. Both Khun Phan and his fellow retiree had survived harrowing brushes with death and became renowned as men with tough hides (khon tai nang niaw), impervious to blades and bullets. The amulets that were minted in May 1963 were humble objects given a false patina of age to render them antique in appearance and mythic (Ek 2010: 32-9). But whatever favour these amulets found with consumers in the marketplace was overshadowed by the Jatukham-Ramathep deity when it was conjured in the late 1980s 
with Khun Phan's indispensable counsel. His wisdom about these matters was instrumental in identifying the deity that announced its presence through a spirit medium.

Early in his career, Khun Phan had been initiated by senior teachers who cultivated the dark arts-what the Thai call saiyasat, a term derived from a Khmer word for excellence or expertise (Baker and Pasuk 2010: 944). In a hierarchical ranking of saiyasat powers, Khmer magic trumps Thai magic; Lao magic lies at the bottom of the tree (Okha 2007: 57). The apparently non-Buddhist aspect of much saiyasat practice is often denigrated by orthodox monastic and lay Buddhists. At the same time, the practitioners of saiyasat are almost always monks or men who have disrobed and left the monkhood where they acquired their expertise from Buddhist master teachers. Knowledge of this complex of practices that can release the forces of nature is useful to warriors and fighters on both sides of the law. Many early Southeast Asian inscriptions contained curses and imprecations against anyone who would tamper with the religious image whose installation was commemorated in the epigraph. I refrain from using the term Tantric, because it does not occur in the Thai materials and evidence for Tantrism in Thailand seems thin. In Tantric Theravada practice in Cambodia, 'left-hand' worldly goals such as the protection and destruction of enemies are reminiscent of Hindu Tantra (Crosby 2000: 162-3). This arcane knowledge reaches back to the Vedas, the fourth volume of which deals with ways to influence natural forces, acquire protection against calamity and human perfidy and conjure supernatural powers. ${ }^{1}$ For the policeman, magical beliefs and practices were a resource, a mother lode of potentialities on which he could draw to keep himself alive and safe in the threatening situations he encountered as he went about his duties. Khun Phan was a lifelong exponent of the knowledge handed down to him by the master teachers in the cave monastery. His bandit adversaries were also initiated into this knowledge in rituals conducted by these same master teachers and their disciples.

Magic - the term often associated with saiyasat knowledge-is an exotic word and we moderns do not think it is part of our lives except in the theatre or parlour trickery. In using it, we consign magic to the other

1 In Thai, the compilation is known as athan or athanpawet. Baker and Pasuk say that the link between Atharva Veda and the Thai concept of athan is tantalisingly unknown, although the Royal Institute dictionary affirms a direct connection (Baker and Pasuk 2013: 228-9). See also Baker and Pasuk (2010: 942-5). 
and make it a binary opposite of reason: 'I think rationally, scientifically; belief in magic and the supernatural — that is the way others think.' The Other is unreason, or apparent reason, which is the conventional domain of anthropological study that seeks to 'de-exoticise what may otherwise be deemed exotic and strange’ (Kapferer 2002: 2-5). De-exoticising does not discredit the exotic and strange, however, because magic is a matter of belief. 'Nobody seeks out a magician unless he believes in him', the French anthropologist Marcel Mauss stated emphatically (Mauss 2010: 113). Science is also a belief system, but one that rests on a posteriori beliefs, even if some people reject these beliefs out of hand. 'What are we to make of another culture's apparently false knowledge?' asks Richard Shweder, whose question is answered by Kapferer and Mauss. But Shweder is interested in contemporary society as well as other cultures. The magical thinking we attribute to people in other cultures is little different from how modern people often interpret reality: 'most of us have a "savage" mentality much of the time', says Shweder (1977: 637-8).

Khun Phan's repertoire of self-strengthening practices emboldened him and contributed to the ruthlessness in his character. He acknowledged his savage mentality, cultivated it and deployed it as a weapon. The executioner's tattoos on his hand meant he would cause instant death if he fired a bullet or madness if he threw a punch. The tattoos demonstrated that he would not hesitate to use lethal force. The performative aspect of Khun Phan's play with magic was not unique to this policeman from Thailand's mid south. Executioners in many societies use spells and charms to catch their adversaries (Mauss 2010: 37).

Writing about the Trobriand Islands, Malinowski suggested that magic supplies men and women 'with a number of ready-made ritual acts and beliefs' to confidently carry out important tasks, to maintain poise and mental integrity in fits of anger and in the throes of hate, unrequited love, despair and anxiety. The function of magic, he writes, is to ritualise human optimism, to enhance faith in the triumph of hope over fear (Malinowski 1974: 90). Magic and the sciences of protection and prognostication are as much about bolstering confidence and maintaining optimism as they are about thwarting evil. Magic belongs to the psychosocial dimension of human experience. It treats the emotions and humanity's expressive needs rather than the rational faculties, but this is not to say that it is irrational. It is a highly determinate system whose rules and procedures, which are empirical and precise yet always subject to modification and adjustment, have an integrity all their own. The system-a sacred canopy thrown over 
human behaviour-has an inner logic and is entirely self-confirming. It gives reasons to decide to do this rather than that, on this day rather than another one.

\section{Amulets and protection}

Many of the measures Khun Phan employed were aimed at building confidence and reducing the possibility of failure. Not least of these were his boasts of owning objects with special powers, including krises, the daggers emblematic of Malay sovereignty that possessed supernatural powers, and amulets, some of them seized from the bandits he had captured. In Khun Phan's time, police as well as bandits armed themselves with objects that were as necessary to their defence as a weapon. The warrior castes-policemen and soldiers-are keen consumers and connoisseurs of these objects. Buddha amulets confer or enhance personality traits and offer protection; other objects have magnetic properties that attract wealth, supporters or auspiciousness in all its forms. A distinction is made between Buddha amulets-which encase small images of the Buddha, saints or eminent monks — and other kinds of amulets, such as the Jatukham-Ramathep deity, or takrut, which are small cylinders tied around the neck, waist or upper arm. The cylinder contains a thin pliable sheet of rolled metal such as tin, inscribed with the kabbalistic diagrams and formulae that confer protective powers (yantra).

The Thai police force has never stopped modernising, and the latest forensic techniques are now more important than ever in combating terrorism and identifying human remains left in the wake of natural disasters. Yet a serving policeman of my acquaintance proudly showed me the scars where his policeman uncle had slit the skin in the flesh of each upper arm and inserted tiny takrut. Even today's policeman wants to hedge against the risk of injury or death by utilising all available methods.

In former times, metallic objects were inserted under the skin in the forearm as a physical as well as a spiritual shield, a barrier against blows from a sword or cudgel. An elusive silvery substance of mercurylike appearance known as leklai (lit. 'fluid iron') was, and perhaps still is, a favoured choice for this purpose. It is harvested in caves by monks familiar with Brahmanic expertise using a naked flame and special chants that render the substance pliable and malleable for working into small silver oblongs or images, including Buddha images (Daeng 2006; 
Thotsaphon 2012). On one visit to Nakhon Si Thammarat, I was promised a viewing of this material with its ineffable qualities, but the opportunity never materialised. The sceptical modern might say that the specificity of the properties of leklai, its sources of supply and the methods of its extraction are in inverse proportion to the likeliness of its existence, yet it is discussion of substances such as leklai that keeps the reality of the supernatural in circulation. A description of one of the skilled warriors in the epic poem Khun Chang Khun Phaen pictures a rather grotesque, misshapen human figure once it is equipped with these dermal shields:

He had a jet gem embedded in his head, golden needles in each shoulder, a large diamond in the middle of his forehead, a lump of fluid metal (leklai) in his chest, and herbal amber and cat's eye in his back.

His whole body was a mass of lumps and bumps in ranks and rows. Since birth he had never been touched by a weapon, and did not carry even the scratch from a thorn. (Baker and Pasuk 2010: 631)

Amulets can not only shield their owners, but also make them rich. They belong to a class of auspicious objects capable of attracting wealth and good fortune. Some objects are explicitly Buddhist or display distinctively Buddhist elements, while others, such as lucky fish (pla taphian) or turtles, are secular. Consecrated stones, 'golden dolls' (kuman thong), linga cast from bronze or carved out of timber and therapeutic herbs also belong to this class. The Thai epic poem mentions bits of tusk left in trees or antheaps by raging elephants in musth. Bees' wax, if given the right treatment and applied to the lips, is a most effective love charm (Klam 2008: 109-10). Such intrinsically powerful objects (sing saksit) are found in many cultures, as a little Thai book with Nepalese, Peruvian, Hindu, Judaeo-Christian and Native American examples makes clear (Jaturawit 2008). Tucked away in restaurants and shop houses in Thailand and in Thai-owned establishments abroad may be found an image of Nang Kwak, a female figurine beckoning to passers-by to venture inside and make a purchase to boost the day's takings. The powers of such objects obey the laws of attraction, to borrow from the title of a pop psychology manual; the scientific pretence of the enterprise may be gauged from the publisher Physics Centre (Wisit 2008). Thai gurus with a smattering of overseas education build their reputations by marketing manuals that promise profit and success if the prescribed regimens are strictly followed. 
The power in amulets is not abstract or amorphous. It is concrete, and the universe is lumpy with it, rather like the mana in Melanesian and Polynesian cultures that suffuses everywhere and can take material form in nature and in the human-made world. The spirit stones found in Chinese gardens and courtyards, much prized by collectors and connoisseurs, exhibit similar properties. The strange shapes of spirit stones with their sharp overhangs and pocked, craggy surfaces are never completely natural after an artisan's careful tooling. Chinese scholars were inspired by the stones and saw them as imbued with the generative properties of the earth and as a manifestation of the organic structure of the universe (Little 1999). In the compounds of Thai monasteries, one comes upon miniature grottoes studded with small stupas and other reliquaries that morphologically resemble Chinese spirit stones. The strange, otherworldly appearance of the grottoes holds the onlooker's gaze.

In Thai language, objects that concentrate mana are called auspicious matter (watthu mongkhon). If it is a mass-produced amulet, the object is stamped from a powdered compound (phong) containing ash, ground-up tiles from a famous monastery and therapeutic plants. Herbs such as hang jorakhe, a styptic used for small cuts and the treatment of burns, are said to protect against bullets and sharp objects. An amulet created by the king in the mid-1960s and affixed to a Buddha image he had commissioned contained the king's hair and nail clippings. By means of ritual, the amulet is charged (pluk sek) by the spoken words of the monks and transformed into a powerful object (khreuang rang khong khlang). The power it has acquired is phalang - the word also for nuclear, atomic and hydraulic energy as well as people power and the power to struggle and fight.

Those trading in these objects sometimes endow them with a scientific reality by saying they 'emit' as though radioactive (Chalong 2013: 204). Like the half-life of a radioactive isotope, the charge weakens over time, or can be lost entirely if the person wearing the amulet walks under a footbridge and exposes it to the polluting effects of pedestrians treading overhead. Khun Phan's son Chanthip said his father did not allow other people to touch his kit lest the objects be sapped of their special powers that protected him. ${ }^{2}$ The local historian from Chawang District in Nakhon, Chali Sinlaparasmi, used to run into Khun Phan in town, where they would both enjoy sticky rice roasted in bamboo. When he asked the policeman why he was wearing so many amulets, Khun Phan

2 Chanthip Phantharakratchadet, Interview with the author, 9 September 2012. 
replied that he feared the spirits of those he had killed and he needed to protect himself. ${ }^{3}$ Once an amulet is consecrated it becomes a magnet that can attract customers, lovers, clients or constituencies. The properties of attraction (mettamahaniyom) attach to the person who owns such a consecrated object, and thus they become an asset useful to politicians, village headmen, gangsters or businesspeople. ${ }^{4}$ Anyone needing to build and hold the loyalty of an entourage wants to own these lumps of special stuff. The magnetic force of mettamahaniyom makes a man attractive, endowing him with personal charm (saneh) that can even be erotic. Khun Phan himself had 'the right stuff', as an early American astronaut might have said.

In this case, the stuff is manliness. There is a distinctly masculine aspect to the interest and trade in amulets across all socioeconomic classes that connects to the struggle for power in Thailand that today is still mainly a male affair. The ethnographer Irene Stengs calls the male obsession with amulets a fetish of modern Thai men and describes a small amulet market in Chiang Mai as exuding a 'typical masculine atmosphere', with all the male vendors wearing dark sunglasses, with long hair, tattoos and sporting well-toned muscles (Stengs 1998: 56, 69). It is not only in an upcountry amulet market that one sees such types; motorcycle-taxi drivers waiting for their customers at the mouth of a Bangkok lane could be described in the same way. In more upmarket places, brokers may be dressed in smart casual or business attire. While women traders may sell the cheaper, mass-market items in the amulet markets, the brokers who trade the most valuable amulets and charms are usually male.

Though it is seldom acknowledged, the maleness of the Buddha is evident in many texts and observances. It is said that his sexual prowess was such that he could satisfy 60,000 courtesans; his penis could extend from its sheath, wind around Mount Sumeru seven times, and extend upward to the Brahma heaven (Powers 2009: 13-14). Potency is one of the glosses for the powers (iddhi) of the Buddha. The trade in amulets-particularly Buddhist amulets - and the exchange of information about valuations, qualities and brokers are elements in male bonding. Even the giving of amulets is a male thing: fathers, brothers and uncles present them to female as well as male relatives. Women have their own consumer preferences and are not keen collectors.

3 Chali Sinlaparasami, Interview with the author, 7 September 2012.

4 Baker and Pasuk (2013: 224-5) identify the spoken or chanted formulas for charging objects with the force of attraction or repulsion. 


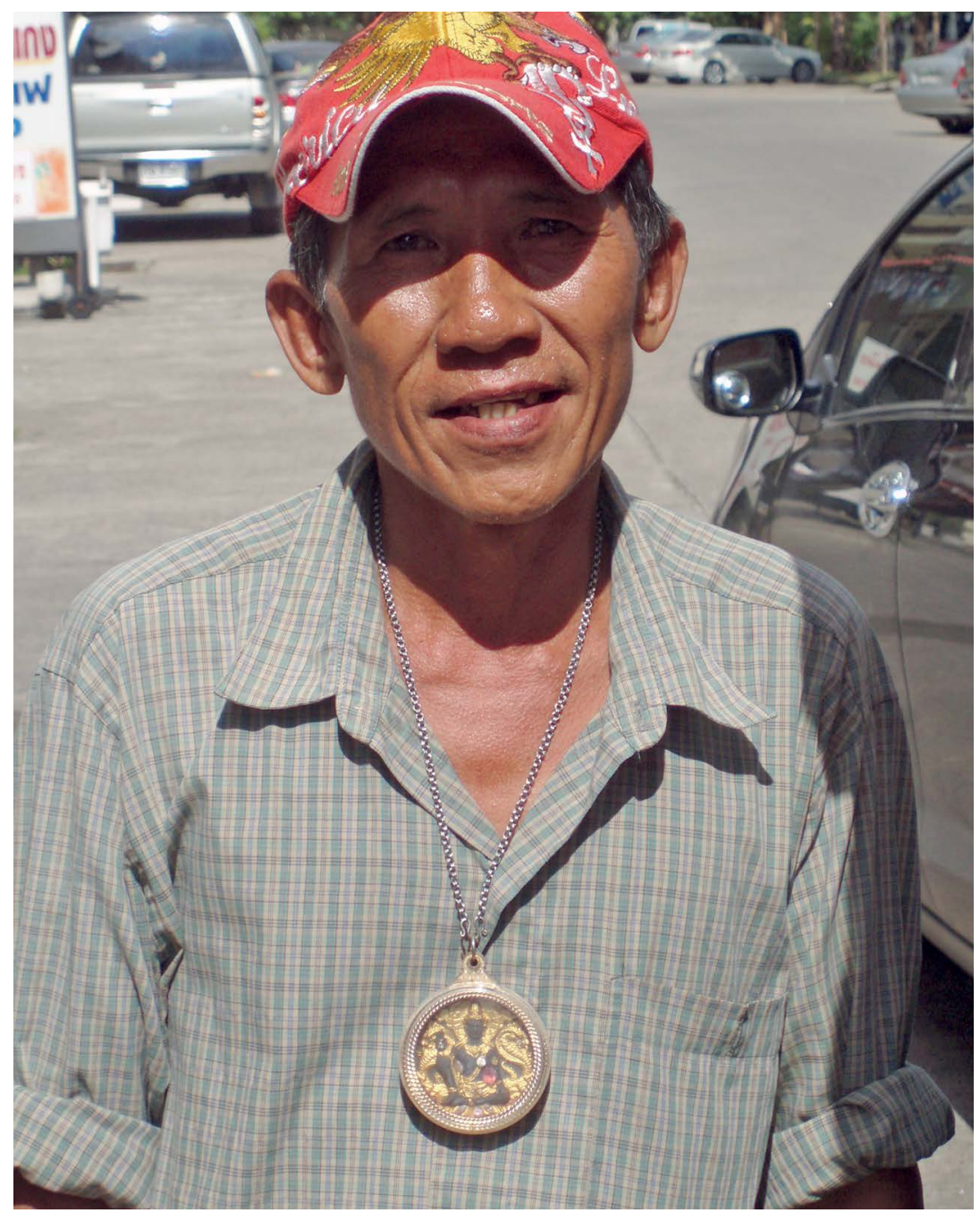

Plate 8 Fruit seller wearing the Jatukham-Ramathep amulet, Nakhon Si Thammarat

Source: Craig Reynolds.

Sales of early editions of the Jatukham-Ramathep amulet were slow among the female demographic, because the large cookie-sized objects were considered too macho for women, especially young women. Many Thai women, although I hesitate to essentialise the point, want something smaller, daintier and more feminine to wear around their necks. They prefer to buy and wear a locket (lokhet) rather than adorn themselves with a clunky amulet (Stengs 1998: 70). 
Khun Phan was an astute observer of the world of auspicious objects (watthu mongkhon) and a student of the rites that brought them into existence. In 1976, he wrote an essay for a southern Thai magazine that was basically an inventory valorising auspicious objects and expounding on their characteristics and benefits. He offered his own definition of saiyasat:

Saiyasat is a form of knowledge about spells and chants that has flourished in India from ancient times. It is a kind of knowledge that branched off from the eighteen Great Puranas which anyone seeking to excel above others [phu thi cha pen yot khon] needed to learn and be fully conversant in. Siddhartha himself [the Buddha] studied saiyasat as well as the eighteen sciences and became expert in all of them. Saiyasat is the life-force of the Thai people. (Phantharakratchadet 2007: 470) ${ }^{5}$

Thai people, he writes, have made use of saiyasat from the cradle to the grave, and he goes on to explain that those in possession of this knowledge have more connection and more rapport with the general public than monks who teach the way of the Dhamma-a claim that at first sight seems extraordinary but that explains why Khun Phan valued this knowledge as beneficial in his police work. He had firsthand knowledge of the mental universe of the people in the districts he patrolled. In his essay, he reiterates the importance of saiyasat for conducting the good life through one's behaviour, speech and thought. The master teacher extracts a pledge from the student adept to conduct himself properly. There are prohibitions against this or that: one should not curse one's mother, for example, or be cruel or betray others or commit adultery. Someone adept at saiyasat must be trustworthy, diligent and mentally tough (mi samathi), and neither fearful nor shy. The master teacher should assess the student's adeptness and decide which is the most appropriate path according to the student's personal qualities and abilities. Not even the 16 Buddhist saints or the Buddha's disciples were adept in all branches of magical knowledge because their powers (iddhi) were all different. This moral code and the personal qualities that maintain it recall the pledge the southern policeman made when he was initiated into the dark arts at Wat Khao Or

5 The information in the following paragraph is also taken from these pages of Phantharakratchadet (2007). I presume the 18 sastra are the Great Puranas. Khun Phan's inventory is reminiscent of the rural Thai rites and practices compiled by the late Robert Textor in the 1950s (Textor 1973). 
at the beginning of his career. Mental toughness and fearlessness stand out as personal qualities befitting a policeman who lived every day he was on active duty in the face of sudden death.

Khun Phan's inventory of auspicious objects and practices runs parallel to the auspicious objects and sciences of prognostication that Baker and Pasuk found in their study of the Thai epic poem Khun Chang Khun Phaen. One of their insights is that mastery of the self gives the adept the ability to control spirits and activate natural forces by using a repertoire of formulas, chants and unusual substances derived by alchemic means (Baker and Pasuk 2013: 230). Khun Phan quotes verses from the poem, so he knew of its elemental knowledge about auspicious objects and their powers. I am tempted to say that the poem was speaking through Khun Phan. In identifying these objects and their characteristics and deploying them during his career, Khun Phan was channelling Khun Phaen, the character in the poem who avails himself of supernatural powers to gain advantage over his nemesis, Khun Chang, a rich, well-connected man in the local town who has held the upper hand in their rivalry. The southern policeman had downloaded a hefty section of the Thai cultural code shared by many people at all levels of Thai society.

Arbiters of Buddhist orthodoxy such as Phya Anuman Rajadhon state categorically that saiyasat has nothing to do with religion; it is a kind of knowledge that lies 'outside' Buddhism (Sathian 1965: 33; Suwit 2011:4). But the boundary between Buddhism and magic is blurred, because the Buddha himself possessed supranormal power (iddhi) as well as potency. A Buddhist text states that 'a bodhisatva can introduce Mt. Sumeru into a grain of mustard and the water of the four oceans into a single pore of his own skin' (Benavides 2006: 295-7). Other non-canonical texts speak of the Buddha's psychic powers. He could fly into the sky, touch the Sun with his hand and make his body into many bodies. He could travel to other realms and converse with the deities there. He knew the thoughts of others and could recollect his own previous births (Reynolds 2005: 218). Yet, while he had attributed to him these extraordinary powers, he denied that he was a magician in any derogatory sense. Given the shaman's ability to travel to other worlds, he might also have denied that he was a shaman. Indeed, a secular definition of awakening or enlightenment is that it recognises the attainment of supreme psychic knowledge. The supernatural powers of the Buddha and his disciple Maudgalyayyana are pervasive in the early literature because such powers facilitated conversion to the Buddha's teachings. 
The altered state of consciousness attained by shamans is the polar opposite of the mental awareness that is the goal of a Theravada Buddhist monk. The meditation techniques mentioned in the early scriptures focus on clarity and understanding the nature of existence. Other kinds of psychic states, such as trance and possession, which have become more popular with the emergence of global Buddhist movements, are at odds with many teachings of the Buddha, yet these practices are commonly found in many Buddhist societies today, including Thailand. Spirit mediums and their clients often conduct business in or near monastery compounds; monks or former monks may serve as vessels for the spirit to visit. While the Buddha rejected a magical or shamanic identity for himself, even a religion that tolerates magic and magical practices conducted by monks or ex-monks maintains a distinction between legitimate and non-legitimate encounters with the supernatural. The monastic ideal is withdrawal from the world and worldly ways; magic embraces the world and provides instruments to control it.

In the Buddha's time, ordinary monks were dissuaded from speaking about the special powers they might have acquired and what they might be used for. The Vinaya, the book of monastic discipline in the Buddhist canon, specifically disapproves of magic, including love magic, curses, astrology and alchemy, by characterising these as 'animal-like knowledge'. There is more than a tinge of elitism in this thinking, so it comes as no surprise that the Thai edition of the Vinaya in wide use today was edited by an aristocratic arbiter of Buddhist practice and thought, Prince Vajrayana, the eminent ecclesiastic brother of King Chulalongkorn who spent his entire adult life in the monkhood (Vajirananavarorasa 1973: 120-1). Yet this 'animal-like knowledge' is what laypeople crave as the savage mentality of the species rises to the surface when challenged by personal crises or natural disasters that call for desperate measures. Lay preoccupations and needs extend beyond the merely spiritual and must be acknowledged and met with the application of saiyasat.

Monks recite two kinds of invocation, paritta and rakkha, for protection; dharani is a synonym of these terms. The paritta recitations-a distinct genre of Buddhist literature found in the Pali tradition-keep a person safe from evil spells, weapons such as knives and guns, betrayal, fire and poison. The monks in these recitations are preaching to the spirits to warn them and to convert them to the way of the Buddha. A regular practice wherever Theravadin Buddhism has been established, paritta recitations are effective because of the sounds uttered in the chanting, and less so 
for the meaning of words, which often has nothing to do with a role in ritual (McDaniel 2004). Audience interest and concentration can be partial if not minimal, with much murmuring and sleeping throughout the proceedings (Tambiah 1970: 195). The performance of the recitation is the key to its effectiveness rather than its reception and internalisation by the listener.

The use of these texts dates from the earliest sutta, chronicles and commentaries in the Buddha's time, with lists of paritta titles to be found in the Questions of Milinda (Milinda-pañha), a composite text that dates from the middle of the second century BCE to the fifth century CE. Burma, Siam and Sri Lanka have parallel paritta traditions (Skilling 1992: 116-17, 120). The recital of paritta produces mental wellbeing in those who hear it, as well as the power of love and a virtuous state of mind. Popular belief holds that reciting the texts is not just rewarding for mental strength, but also efficacious in curing illness and keeping spirits at bay. The texts in the rakkha genre-pan-Indian as well as panBuddhist-are recited in the Mahayana tradition to invoke protection against disease, disaster and malignant spirits, and to avert misfortune of all kinds. Spirits - the embittered, hungry or cruelly murdered deadmay need to be appeased, and spirits dwelling in forests or rivers who have had their realms disturbed by human activity need to be placated. One type of spell, mantra, is recited specifically for worldly or mundane ends, such as warding off calamity or to promote physical wellbeing and welfare. In Sri Lanka, some of the Buddha's sermons were transformed in Mahayana Buddhism into these magical formulas (Saddhatissa 1991: 127; Skilling 1992: 110). The mantras, which are not found in the canon of the Theravadins, have both intelligible and unintelligible elementsphrases that are not arbitrary but are necessary for the efficacy of the mantra. The widespread use of these mantras in Theravada practice has led to a rethinking of what constitutes Theravada belief and practice (Skilling et al. 2012).

Rakkha can be written on paper or cloth and deposited in stupas, tied to banners carried by soldiers in battle or rolled up, encased and worn as takrut amulets (Skilling 1992: 167). These items provide bodily protection for the individual who has invested the time and money for the protective properties of the object once it has been charged by the religious specialist. Men who go to war, hunters in the jungles and forests and people in life-threatening occupations want the benefits of these protective devices. In the absence of an amulet, a mantra honouring 
a famous Buddhist saint such as Upagupta may be recited to thwart harm. Meditation practice also has protective power. Forest-dwelling monks in northeastern Thailand help villagers overcome their fears of spirits or ghosts by teaching meditation that gives the villagers confidence in their own spiritual powers (Kamala 1997: 209). Tattoos on young men, etched by monks who have the requisite skill and knowledge, also have protective and beneficial effects (Terwiel 2012: 77-88).

\section{Auspiciousness and uncertainty}

The manufacture of amulets evolved slowly in Thailand and was revolutionised in the mid-nineteenth century by the introduction of photography and coin-minting technology. During the twentieth century, the Buddhist amulet became a popular magical device for protection, not only for soldiers and police, but also for many others. The unsettled times after World War II, when crime and banditry posed security problems for the government, saw a boost in the popularity of amulets, and a literature began to develop around the phenomenon as specialists classified and ranked the objects for their sacredness and powers. An army major general proposed a league of five to identify the most sacred Buddhist amulets of the Thai nation and elevate them to the top rank. Beginning in the late 1980s and through the 1990s, Thailand's economic boom and prosperity saw religious movements transform amulet trading, marketing and publishing into an industry in its own right. The makeshift stalls in markets moved to shopping malls, where traders display their wares in boutique shops. Brisk business takes place in cyberspace as well, and newspapers run amulet columns for aficionados (Jackson 1999; Chalong 2013: 181-3, 191-2, 203-4).

Amulets of all kinds are popular for their value as commodities, for their characteristics and powers that help people and for their artistic qualities and their beauty. One Saturday in September 2012, I wandered through the Tha Prachan amulet market along the Chao Phraya River near Thammasat University. The regionalisation of Buddhist saints is a recent phenomenon and some stalls were selling trade magazines specialising in amulets that originated in different parts of the country: Chiang Mai, Sukhothai, Kamphaeng Phet, Ayutthaya, Surat Thani. Customers in civilian clothes or in uniform made their way through the aisles, occasionally stopping at a stall to examine their prospective purchase with 
a small magnifying glass or jeweller's loupe-essential tools for the serious amulet buyer. The objects for sale were of mind-boggling variety, and not all of them were sacred. One shop sold small ceramic Chinese sages with a beard and walking stick, 'tiger' fangs packaged in see-through cases and metallic droplets bound in a corded net. Also on sale were Buddha images large and small, busts of famous monks, medallions of Buddhist saints, tiny adept's knives and magical cloths with esoteric symbols (yantra). While food sellers delivered drinks and small dishes of noodles or rice, customers were selling as well as buying, and solicited valuations of what they were offering before bargaining for an agreeable price. Brokers who handle the transactions are known as Sian Phra, sian being a Chinese word for saint. Once a Buddhist amulet is in hand, for a small fee, it can be inserted in a see-through case known in Thai as a talap, the word for 'coffin'. Some brokers conducted their business encased in airconditioned glass cubicles, rather like the precious objects passing through their hands, the comfortable surroundings a reflection of their customers' affluence as much as the quality of the products and services they offered.

The ritual that transforms a stone, a piece of cloth or a mineral into a compound (phong), which is then crafted into an auspicious or powerful object, must be performed at a designated time and place calculated according to astrological manuals. Planning or timing any activity-be it the purchase of a property, the date for a wedding or a coup or the time and place for a thief to break into a house or for the police to try to catch the thief-requires such a calculation. In his 1976 inventory, Khun Phan listed the information required to calculate an auspicious moment or conjuncture (roek): time, day, compass point and place (Phantharakratchadet 2007: 476-7). Families, dynasties, cities and towns as well as individuals have their own horoscopes (Cook 2002: 198). In the mid-1980s, the urgency to recalculate Nakhon Si Thammarat's horoscope triggered the search for the spirit of the Jatukham-Ramathep deity who would restore stability and good fortune to the town.

The methods for identifying conjunctures are provided by applied sciences of prognostication. These are semiotic sciences, ways of reading signs that show the way forward. In the West in the late seventeenth century, astrology found itself eclipsed by probability theory. Knowledge of probabilities in the outcome of an action is by definition incomplete, so we are in the realm of uncertainty and maybe we have to guess about what to do. In Latin languages, 'conjecture' is a term that originates in divination (Ginzburg 1989: 106, 205n.48). Uncertainty is a state of mind 
that arouses its own emotions when a big decision looms or routine is suddenly disrupted and we need guidance. When to proceed? Which way to go? The science of prognostication enables people to face the uncertainty and unpredictability of life, to deal with misfortune, injury or death and to anticipate an outcome, whether or not it is favourable. People look forward as well as backward. They make plans and decisions about the next day or the next week. They assess risks and opportunities in personal relationships, in business and in the workplace. They dream of success. They abhor failure and strive to discern the odds to avoid it. Astrology, an applied science, involves reading and interpreting birth signs and using the information to make appropriate decisions to render guesswork unnecessary and optimise outcomes.

The keyword in the applied science of astrology is 'auspicious' (Skt, mangala; Th., mongkhon), a concept found in Hinduism and Jainism. Some translations of this word are luck, fortune, happiness, prosperity, welfare, auspiciousness, good omen, lucky object, amulet and festival. The Scripture about Auspicious Things (Pali, Mangalasutta) in the Theravada Buddhist canon consists of only 12 verses, but it is one of the most influential texts in the Theravada world from Sri Lanka to Southeast Asia and is often recited during the protective rituals performed by monks to ward off misfortune. The introduction to the Mangalasutta explains that a long discussion took place among gods and humans about what mangala means-a discussion that connects with the audience by mentioning various types of good and bad omens. The subtext is that The Scripture about Auspicious Things recognises the diversity of local contexts and traditions in which Buddhism took root and adapted to local conditions. The Scripture about Auspicious Things also recognises what Hallisey calls the shadows of a harsh world of agricultural labour and hard work in the largely peasant societies where Theravada Buddhism has thrived for centuries (Hallisey 1995: 413-14). This Pali text on auspiciousness has received the most attention in Thai history for its genre, based on a commentary composed in Chiang Mai in 1535 CE. It is also identified in at least one manuscript as a paritta, a protective text (McDaniel 2008: 134, 166, 293n.12).

The annals of Southeast Asian history are full of examples of auspicious timing determined by horoscopes and omens, particularly in times of war, although most historians skip over these details to get to 'the facts'. The French historian Aurore Candier has broken through modern scepticism by demonstrating how Burmese prophecies affected the 
strategic thinking of Western imperialists as well as the Burmese court as the British pushed into Burma during the second half of the nineteenth century. In his dealings with the British, the reigning monarch, King Mindon (r. 1853-78), was empowered by auspicious forecasts based on prophecies, omens and rumours. By the same token, the king's capacity to influence events was adversely affected by inauspicious forecasts. The British exploited the fear stirred by the Burmese prophecies, omens and rumours and pressured the Burmese king to agree to their demands. Candier was able to illustrate how historical events and conjunctures identified by astrological forecasts are related by cause and effect (Candier 2011: 235, 256).

Astrological calculations that determine a time to conduct an important event are only one of the semiotic sciences of divination that show the way forward. Other sciences of prognostication include palmistry, deciphering facial features, the interpretation of moles and freckles, the interpretation of dreams and reading the landscape. In Thailand, the archive of information on what signs to read and how to read them is the manual tradition of phrommachat (lit. 'Brahma-born' or 'Brahmanic lineage'). The role played by Brahmans in Siamese statecraft and royal rituals such as coronations and the ploughing and swing ceremonies is well documented, but the popular use of phrommachat knowledge in the management of daily affairs by people in all social classes has received little attention in Western scholarship. An exception is a book by the occasionally astute Quaritch Wales on divination that seems to be based almost entirely on a phrommachat manual of 1885 that Wales located in the British Library (Wales 1983: $\mathrm{x}$-xi). In addition to horoscopes and other semiotic sciences such as palmistry and interpreting anatomical marks, the phrommachat manuals contain information on the colour associated with each day of the week, the animal associated with each year in the 12-year cycle, the characteristics of the cardinal directions and the deities that preside over each point. The Hindu gods Shiva, Vishnu and Brahma are only a few of the deities whose actions have an impact on the terrestrial world.

The semiotic sciences and associated ritual practices, including tantric Buddhism or saiyasat that involved knowledge of the Vedas, were prevalent in both the elite and the subaltern classes in the early Bangkok period. By the first half of the twentieth century, according to one study, there were 683 manuals in the National Library of Thailand concerning saiyasat, some of the phrommachat manuscripts dated from the very beginning of the Bangkok period in the late eighteenth century (Patthamakon 1996: 23). 
The encounter with the West and some of the more practical applications of Western science by the nobility and royal families around the middle of the nineteenth century had an impact on elite thinking. Members of the aristocracy became intrigued with clocked time, for example, which gradually changed conceptions of time by introducing mechanically measured time in contrast to auspicious/inauspicious time, which had governed the way people made decisions and ordered their lives.

By 1900, the manual knowledge of phrommachat had been transformed by the printing press. Entrepreneurial publishers who foresaw the popularity of a printed edition and invested in the venture made the book a commercial success. The royal library had declined to publish the material, regarding it as outside its brief, and gave the manuscripts to private firms. What had previously been a corpus of knowledge scattered in manuscript versions in royal libraries and monasteries throughout the country was gathered up and compiled in a single volume. One of the editions of this published compilation of phrommachat manuals, subtitled the 'People's Edition for Household Use and Self-Instruction', can be purchased in Thailand today; smaller editions can be found for sale in Bangkok and provincial bookstores (Thep 1978).

The 'People's Edition' is an unwieldy tome of nearly 700 pages that bears the traces of its previous history as a heterodox compendium of lists, charts, chants, diagrams, drawings, sample horoscopes and details about numerology. For the specialist, there is even arcane information about Thai dominoes. The book is given the stamp of authority in the front matter with photographs of the palace astrologer and other royal Brahmans. The content is clearly categorised, but overall the organisation is haphazard, as though the various sections were tossed into the air and floated randomly down to form a book. The compiler's inclusion of everything - tables, charts, lists and graphics - contrasts with older manuals in which the knowledge was rare and privileged and required a master teacher to explain.

In the premodern era, time was like a lord with the power to reward or punish depending on the auspiciousness of an event (Patthamakon 1996: 42). The common perception of the phrommachat manuals is that they come from an earlier time and are retained in the present day rather as one might hold on to a family heirloom. Yet the continued use of astrology and other sciences for reckoning when and where to undertake an activity indicates that this knowledge continues to be of contemporary 
use. Knowledge from the manuals in various forms is still highly regarded by cultivators in deciding when to plant and when to harvest (Farrelly et al. 2011: 244-6). For advice to the busy and overworked homemaker, a recent edition of the phrommachat manual contains tips on cleaning and home management, herbal medicine and mental and physical health; how to remove unpleasant odours from the refrigerator; how to clean a clothes iron of rust; and how to keep ants out of the pantry (Saksit n.d.). The phrommachat of old typically had detailed information on when to schedule the humdrum chores of everyday life. Pages and pages are devoted to horoscopes and how to counter the adverse influences of one's birth sign. Nowadays, young people navigating their way through the choppy waters of adolescent uncertainty or house buyers wondering whether they should purchase what seems to be overpriced real estate are keen observers of the numbers and other conjunctures of their birth signs that bode well or ill for their decisions. People trying to find their way in life rely on the cosmic choreography of the planets to help them decide. In the Thai student groups I have known through the years, there always seems to be one person in the cohort adept at reading horoscopes and able to advise their friends on what lies in store for them. The journalist Wassana Nanuam has written several books showing how the logic of astrological calculations has affected the thinking of politicians, military officers and national leaders by identifying auspicious locations and determining the timing of important events. On the basis of interviews with 'big-shot army officers' (bik thahan), Wassana (2009) explains how astrological information enters into decisions about promotions in the upper echelons of the army. Over a decade ago, soldier-politicians decided that a date filled with nines in the reign of the ninth king of the Bangkok dynasty was a good day for their coup. The numbers in the coup date, 19 September 2006, were auspicious: the nineteenth day of the ninth month of the ninth year in the decade of the Buddhist Era, BE 2449. The coup became known as the royal coup.

This numerology may figure in strategic thinking elsewhere in the region. The indefatigable Italian journalist Tiziano Terzani stated confidently that counterespionage agencies in China, Vietnam, India and South Korea have astrology units to anticipate what their adversaries as well as their allies will advise in given situations (Terzani 1998: 75). Similarly, in Indonesia and Cambodia, the police use the same astrology manuals as burglars to figure out when a crime is likely to be committed so they can prevent the act by apprehending the thieves in advance (Quinn 1975; Broadhurst 
et al. 2015: 58). Scheduling, planning and timing are all-important in war and strategy, personal as well as political. In cultures where a systemic numerology links time, nature and human affairs, it is not surprising that numbers should have such a hold on the imagination. Alphanumerics are said to have life within them (Uthai 1979: 4474). At cremations in Thailand, the dates of the ceremony as well as the birth and death dates of the deceased have auspicious portent. The sale of lottery tickets is brisk and the monastery precinct becomes a veritable casino.

Decoding the alphanumerics is a way of deciding whether or not a risk is worth taking, and one sure-fire way to reduce risk is by cheating. In the financial world, this can be done by trading on insider information to buy and sell financial products. In the casino, the roulette table can be rigged or the deck stacked. In the cockfights and buffalo fights in the Thai countryside, animals are drugged or bribes paid. Khun Phan was adept at hedging his risks and could stack the deck in his favour to catch a criminal. With such methods, he could render the risk acceptable if not negligible.

The risk of loss may be ignored in the pursuit of specific ends. Cultivators in agricultural societies do not always make choices for monetary gain but for goals such as demonstrating loyalty, pleasing someone or helping out a friend or relative (Ortiz 1980: 193). Scholars of risk distinguish between 'random situations in which the underlying probabilities are fully known' and uncertainty, referring to 'all other random situations, which knowledge of the probabilities is less than complete' (Clark 1990: 48). It is in the realm of uncertainty where the probabilities are less than complete that people introduce information into their decision-making that might be thought non-rational. Uncertainty can be worrying and cause anxiety and trepidation. One is hesitant to act. The information found in the manuals from the Brahman lineage is systemic and logical and, if applied successfully by a trusted diviner, reassuring. The moment of the conjuncture is calculated by the astrologer from the astral and planetary alignments and the numbers encoded in one's birth sign personalise the decision to be made and reduce uncertainty about its outcome (Baker and Pasuk 2013: 221-2). The conjuncture, which connects the numbers in an individual's horoscope to forces and dynamics outside the range of ordinary human perception, is at once cosmic and personal. In Thailand, the cosmic is never far from the mundane. 
Horoscopes personalise decision-making in the direction of action that will be auspicious, and the possession of the right amulets is another avenue by which to maximise auspicious outcomes. Given the magnitude of the amulet trade, which the vernacular refers to as commercial Buddhism (phutthaphanit), the financial aspect of the buying and selling of auspicious objects cannot be ignored. It is estimated that, at the height of JatukhamRamathep fever after Khun Phan's death, Thailand's GDP rose by as much as 0.2 per cent as a result of this amulet alone. Annual turnover in the amulet industry in the early 2000s, including sales and amuletrelated media revenue, could have been about THB15 billion (US\$300 million) (Chalong 2013: 184). The late Dr Pattana Kitiarsa talked about commercial Buddhism in Thailand as the occult economy-a concept he discovered in the African work of Jean and John Comaroff. Pattana saw the occult economy as a populist reaction against 'a centralized and hegemonic Buddhism promoted by the Sangha and Thai state' (Pattana 2008: 132-8; 2012: 112). The theme of capitalism and commercialism shoving religion aside is often on the surface of this kind of analysis, and this view is shared by scholastic modernist monks critical of the market economy and its destructive materialism and consumerism-'the true evils', according to some Buddhist monks. At the height of JatukhamRamathep fever, one of these monks put the amulet in its place by ranking it lower than the Buddha. The guardian deities fused in the Jatukham-Ramathep are merely custodians of the Great Relic in Nakhon $\mathrm{Si}$ Thammarat; they are not worthy of receiving the same homage as that paid to the Buddha. The saving knowledge of the Buddha, the Dhamma, he argued, is superior to any powers attributed to an amulet named after guardian deities. The monk warned people about being duped by the promises of the Jatukham-Ramathep. Worshipping it could cause society to lose its way (Phromkhunnaphon 2007: 5).

People may be devout Buddhists, but they can be enticed by auspicious objects whose expensive purchase promises reward and, for that reason, the objects are considered efficacious. It is as common to hear the expression phutthaphanit from devout Buddhists as it is from nonbelievers and sceptics. The owner of an authentic, valuable and famous amulet is well aware that the auspicious object has a monetary value. While the sell/ buy transaction renders these objects a commodity, in the case of Buddha amulets (phra khrueang), the object is said in Thai language to be not sold and purchased but leased (hai chao). This terminology presumably purges the transaction of the worldliness associated with the grubby business 
of attaching monetary value to a sacred object. If the transaction occurs at a monastery, however, it is an act of merit-making. In the frame of commercial Buddhism, the objects have value as an asset class for those who trade in them. In this asset class, as with any asset class, some items retain their value or even appreciate in value over time, while the value of other items exhibits volatility, sometimes rising to heights undreamed of before crashing if supply greatly outstrips demand. As an example of how a marketing push through police ranks alone could flood the market, in the early months of 2007, police in Nakhon Si Thammarat were given an option to buy 10 'sets' of Jatukham-Ramathep amulets at THB1,000 (US\$28) per set. They could keep their allocation, but provincial police are not that affluent, so they had an incentive to recoup their costs by onselling the sets. If each of 4,000 police officers in the province onsold their set of 10 at THB1,000 per set-a generous assumption given the volume of the objects coming on to the market-the transactions would have yielded THB 40 million (about US\$1.25 million at the time). With such oversupply in this model it is no wonder the bubble burst in the months following Khun Phan's cremation. The rural policeman who told me this story had a fistful of Jatukham-Ramathep amulets but appeared to pay the objects little heed and said he never wore them. ${ }^{6}$

The volatile, risky amulet investments are what financial advisers call alternative investments. Whether investment in an object is conservative, in the expectation of gradual appreciation over time, or aggressive-risky, by riding an inflationary spike, the asset can be liquidated when the owner wishes, provided a buyer can be found, to release funds for a house purchase, school fees or a family wedding, or the funds may be used to rescue a financially troubled business with a quick infusion of cash. A policeman I met with to discuss the amulet business, after assuring me that he never parted with his amulets, subsequently sold two amulets for US $\$ 31,500$. 'He needed the money', I was told. ${ }^{7}$ No tax is paid on these private transactions, which are useful in disguising profits. Politicians are said to launder money in this way.

6 Conversation with Police Sub-Lieutenant Somthop Chuphom, Cha-uat District, Nakhon Si Thammarat, 7 September 2012.

7 Thongchai Liitpornsawan, Personal communication, 13 September 2012. 
Buddha amulets can also be status markers and, if famous and valuable, mark the social position of those who wear them. A former Thai prime minister alighted from his Mercedes one day and a first-edition cookiesized Jatukham-Ramathep amulet happened to tumble out of his opennecked shirt. Another celebrity, the businessman Sondhi Limthongkul, who led the antigovernment rallies in 2005-06, appeared on camera with his first-edition Jatukham-Ramathep amulet to describe how he nearly died of his injuries when someone tried to assassinate him. The amulet saved him from a hail of bullets that riddled his automobile. Sondhi's miraculous survival made the amulet even more famous. Status also accrues through connoisseurship as collectors acquire the skills to distinguish the real from the fake and build collections that become valuable enough to bequeath to their heirs. The home that houses these heirlooms must be secured with strong locks and barred windows, and it is best not to make too public the existence of one's hard-won collection.

Police officers boast of famous amulets they own and love to have their photographs taken with them, as did Khun Phan and his fellow retiree when they commissioned their amulets in 1963. Members of the public, including policemen, organise the manufacture of amulets to raise funds for monastery buildings, schools and hospitals as well as to enhance their status as public-spirited citizens.

A fundraising campaign was instigated in the early 1950s by Police General Phao Siyanon for renovations to the sanctuary and classrooms at Wat Intharawihan, a monastery along the Chao Phraya River that dates from the mid-eighteenth century, before the founding of Bangkok. Police General Phao, then at the height of his powers, was both Minister of the Interior and national police chief. He solicited the assistance of civil servants and merchants to help him in the campaign and, in October and November 1952, 84,000 triangular and rectilinear amulets were minted and made available to the public for THB10 (US\$0.47) each. The number 84,000 was auspicious; in the third century BCE, the Mauryan Emperor Ashoka constructed 84,000 stupas containing relics of the Buddha. The consecration of the amulets was attended by senior monks of national repute as well as the spirits of four deceased monks, including Somdet To, the maverick monk of Wat Rakhang in the early Bangkok period whose amulets were already pricey because of their magical powers and stable value (McDaniel 2011: 189-90). Police General Phao's amulet is known as 'Somdet Phao' (Ek 2010: 21-7). The Somdet Phao and the Somdet To amulets look very much alike, and one wonders whether the incautious 
or inexperienced merit-making consumer-collector might mistake one for the other. Perhaps no confusion was intended, and Phao just liked the look of the Somdet To and wished to emulate it and let his creation bask in its resemblance to the famous Other. Despite the grandiosity of the event in 1952, the Somdet Phao amulet fell short of Somdet To's monetary and magical value. After Phao's forced exile to Switzerland after Sarit's coup in 1957, the Somdet Phao's value diminished sharply. The amulet he commissioned had failed to protect its creator from adversity.

\section{A deity conjured from ancient heritage}

A few metres from the bronze statue of Khun Phan in front of the Nakhon $\mathrm{Si}$ Thammarat police station, a statue of the Jatukham-Ramathep deity is adorned with regalia and shaded by a faux-gilt nine-tiered parasol. The left leg is tucked to the side of the seated image in a posture awkward except for yoga practitioners; the right leg is upright and the right hand rests on the knee. The chest is muscular, rather like the 'six-pack' abdominals favoured by bodybuilders. The image is modern, and it is not a Buddha, nor is it exactly Hindu, as one Thai friend declared, telling me emphatically when I brought it to his attention that it was 'Indian' (khaek). Such an attribution is understandable. Some Jatukham-Ramathep images in Nakhon are black, as though to reference Hinduism or the Tamils in Nakhon's past. It is not even clear whether the deity is a Bodhisattva-a Buddha-to-be who remains in the world to teach the Dhamma. The deity in its present material form is newborn and came into this world a little over 30 years ago when an amulet was minted to fund a local shrine. 


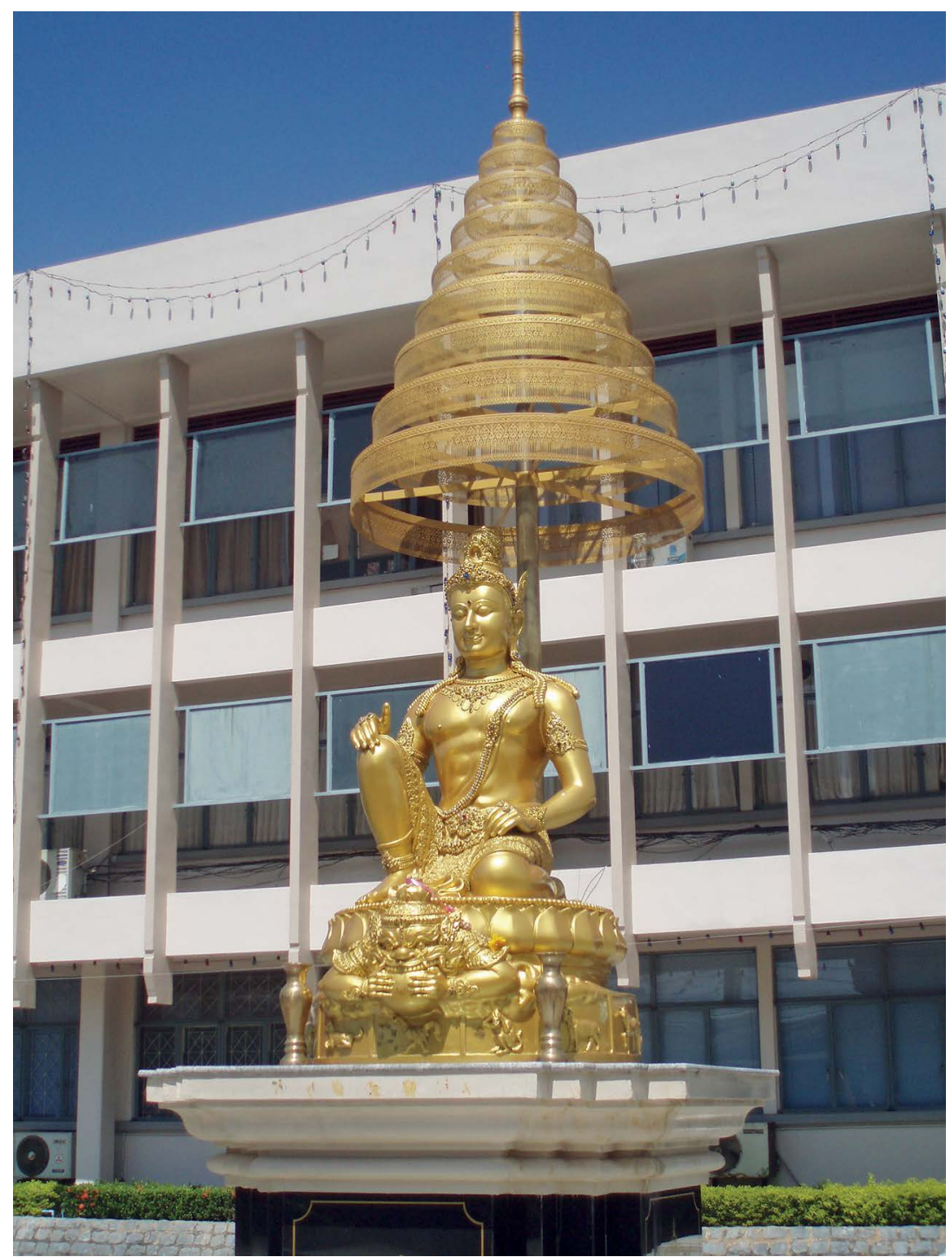

Plate 9 The Jatukham-Ramathep deity outside Nakhon Si Thammarat police station

Source: Craig Reynolds.

In 1985, a new provincial police chief arrived in Nakhon Si Thammarat. Police Colonel (later Lieutenant General) Sanphet Thammathikun was a native of the town and a no-nonsense officer who had spent much of his career posted to other provinces. He had received counterinsurgency training from the Americans and was an expert marksman, able to shoot 
mangoes out of a tree into the waiting arms of an assistant. He was known for his terrorising tactic of placing coffins around the district as a warning, and his job now was to curtail the communist insurgency and end public unrest in the district. ${ }^{8}$ In fact, by the mid-1980s, the communist movement in Thailand was a spent force. An amnesty had been granted to those who had fled into the jungle and the arms of the party after the 1976 massacre at Thammasat University. Still, the communist spectre continued to be raised to justify high defence budgets and to buttress the authority of the security services. Local people soon made the new police chief aware of the need to construct a city pillar (lak mueang), the palladium of the town and the abode of the guardian spirit that watched over it. During the 1980s, the economy had diversified in the provinces. The central government was boosting regional identity and a national effort was under way to furnish each of the major centres in the country with a city pillar.

In the early religious systems of monsoon Asia, territorial stone-spirits assimilated ancestral cults to fuse place, deity and sovereignty (Mus 2011). The Jatukham-Ramathep deity exemplifies such an amalgam, as does the city pillar in Nakhon. While the Great Relic in the town's ancient monastery commemorated the city's triumphant past, it did not fulfil the functions of a city pillar, and the existing foundation stone (bin $l a k$ ) to the north of the town was far too modest, according to urgently made assessments. Police Lieutenant General Sanphet had privileged knowledge of Nakhon Si Thammarat's horoscope. He knew of a curse on the city and wanted to reverse any misfortune that might befall it. Before construction of the new city pillar and its shrine could begin, however, the old horoscope was ritually burnt to remedy the curse and a new horoscope divined to revive the city's fortunes (Phuttharat 2007: 108-9).

A group of Chinese merchants led the new police chief to a Chinese shrine near Wat Nang Phraya to the east of the town, where a spirit medium was known to conjure lucky numbers for the lottery and other gambling ventures. Wat Nang Phaya (Map 3) was not an affluent monastery and the wat committee was always looking for resources to renovate it, so a spirit medium popular with people eager for tips on numbers was helpful to its budget. The monastery was named after Jao Mae Nang Phaya, the mother of the Jatukham-Ramathep deity—as yet unidentified in the material

8 Phirayu (2007: 24, 190-1); Conversation with provincial policeman, Nakhon Si Thammarat, 7 September 2012. 
form that would soon reveal itself. A local community association known as The '28 Society, which had named itself after the year of its founding in the Buddhist Era 2528 (1985 CE), took charge of organising the séances and preparing offerings for the medium. Sanphet was at first sceptical of the medium, but after performing a few experiments to satisfy himself of its authenticity, he decided to heed its advice, and not only about spiritual matters. With crime and public disorder rife in town at the time, the spirit medium asked bluntly at one of the séances: 'Why do you let these bad characters go on living?' Soon after, a number of bad characters in the municipality were found dead and public opinion attributed the deaths to the spirit medium's challenge. Fatal encounters with the police in such circumstances are not unknown in the troubled annals of crime suppression in Thailand. Sanphet was known for his terrorising.

According to several versions of the Jatukham-Ramathep's pedigree, the spirit medium drew an indistinct picture and gave instructions to ask the 'the guy with the whiskers' (ai nuat) to explain the drawing. The devotees immediately identified Khun Phan, the legendary policeman who had sported a handlebar moustache throughout his career. When Sanphet and his delegation arrived at Khun Phan's house to hear his interpretation of the puzzling picture, the older policeman was waiting for them as though he had foreknowledge of the visit. He was very excited to see the drawing and immediately identified the image as Jatukham-Ramathep, or Chandrabhanu, the monarch of the ancient Srivijayan kingdom. Police Lieutenant General Sanphet and his Chinese merchant colleagues returned to Wat Nang Phraya to report the news and, through the medium, the spirit of the Jatukham-Ramathep deity spoke up to identify itself, saying: 'I've been waiting for you for a thousand years! Now I'll tell you how to build the city pillar shrine' (Nan Tapi 2007: 11-17). The face of the Jatukham-Ramathep turned out to be a composite of the twin deities guarding the relic chamber under the Great Relic stupa (Chaiyaphong 2007: 64; Nan Tapi 2007: 29; Phuttharat 2007: 125). ${ }^{9}$ The JatukhamRamathep twin deities are regarded as guardians of the town and their images are found elsewhere at Wat Mahathat (Brawn 2018: 151).

9 See Reynolds (2017: xv) for illustrations. The late Michael Wright decoded 'JatukhamRamathep' as two Buddhist guardian deities known in Ceylon: Kataragam (Th., Jatukham-Ramathep, Khattukham), son of Shiva; and Upulwan (Th., Ramthep, Ubonwan), Vishnu or Narai (Matichon Weekly, 26 April 2007: 67; 8 June 2007: 30). Justin McDaniel has also identified Kataragama as a Sinhalese deity (Personal communication, 11 August 2011). Chatukham also means 'city of the four quarters' (Phuttharat 2007: 104-5). 
The deity's spirit is always present but needs material form-a vesselto become manifest in this world. Once the Jatukham-Ramathep gave instructions through the spirit medium, construction of the city pillar could begin, and Jatukham-Ramathep amulets were minted to fund the construction of the shrine, which was formally consecrated in 2000 by the Crown Prince of Thailand (Chaiyaphong 2007: 59-78; Nawamin 2007: 43-5). ${ }^{10}$ The initial edition of the amulet cost THB10-20, and was produced in 1985 by local people. Sales were painfully slow at first; amulets four and five centimetres in diameter were unpopular with some buyers because of their size (Kong Bannathikan Khaosot 2007: 82; Phirayu 2007: 136). In March 1987, the city pillar was finished and, in a rite performed for Hindu and Buddhist guardian deities, it was brought to life when its eyes were ritually opened (poet net) (Nawamin 2007: 56-7).

That the deity's biography exists in present memory is one thing; the history of its incarnations in sculpture and talismanic form is quite another. I have discovered no oral explanation and no authoritative written account to explain the image's iconography. The Jatukham-Ramathep image is a work of bricolage, an amalgam that quotes elements from Hindu and Buddhist precursors. To make identification of its constituent parts even more elusive, the image has changed over the three decades of its life and assumed different postures. Just how the artists and craftsmen decided on the disparate elements that went into its fabrication is difficult to say with confidence, and I can only explore the possibilities.

Small bronze sculptures and votive tablets of Hindu and Buddhist deities dating from Srivijayan times have been found in several mid south provinces-Phatthalung, Songkhla and Trang - as well as in the deep south, often in limestone caves that are difficult to access. Collectors of guano and birds' nests first discovered the tablets. The earliest, dating from the seventh century, comes from Phatthalung. A familiar deity on many tablets is Jambhala (Th., thao chumphon), a Bodhisattva popular with merchants and seafarers who is the Mahayana Buddhist counterpart of Kubera, the Hindu god of wealth and riches, who is identifiable by his protruding belly and corpulence, signifying wealth and abundance.

10 After Khun Phan's cremation, when the Jatukham-Ramathep amulet craze was at fever pitch, five pop-history books were published on the amulet, the construction of the new shrine for the city pillar and Nakhon's legendary history (Chaiyaphong 2007; Nan Tapi 2007; Nawamin 2007; Phuttharat 2007). Police Lieutenant General Sanphet's story is told at length in a lavishly illustrated book published by Sondhi Limthongkun (Phirayu 2007). These books have no footnotes or bibliographies, but they clearly draw on academic works as well as oral accounts. The books by Chaiyaphong (2007) and Nawamin (2007) have black Jatukham-Ramathep images on their covers. 
The terracotta votive tablet of Jambhala from Trang has been identified as tenth century, 'Srivijaya' period, and is seated in the posture of royal ease (rajaliläsana), with one leg crossed in front and the other hanging over the edge of the throne (Pattaratorn 1997: 33, 36, 75). ${ }^{11}$ The stamp is sharp and deep. This posture is common in many Jatukham-Ramathep images, in both amulet form and full-sized.

Sculptures and votive tablets depicting the Bodhisattva Avalokiteśvara have been found in many sites in the mid south, especially at Chaiya. An antecedent image that almost certainly inspired the JatukhamRamathep is an Avalokiteśvara from the eighth and ninth centuriesthat is, late in the Anuradhapura period-now housed in the Colombo National Museum. Michael Wright's columns about the JatukhamRamathep phenomenon reproduce the Late Anuradhapura Avalokiteśvara, but whether the image has been inserted by the publisher or the columnist is not clear, and Wright does not say that it is an antecedent (Wright $2007 \mathrm{~b}, 2007 \mathrm{c}$ ). Yet in posture, sumptuous crown and royal attire, the resemblance with many Jatukham-Ramathep images is striking. Falling over the upper legs is the front section of the hip cloth (dhoti); the headdress is the Bodhisattva's matted hair piled up in a high chignon (jatamukuta). ${ }^{12}$ Many of the Jatukham-Ramathep images are seated in this pose of relaxation (lalitäsana); sometimes the right hand is resting on the knee and sometimes it is raised. In the Anuradhapura image, the abdominal muscles are moulded slightly to emphasise the twisting torso.

Avalokiteśvara enjoyed great popularity in medieval Sri Lanka. The zenith of its fame was the eighth to the tenth centuries, and the saviour cult may have spread from India to Sri Lanka and Southeast Asia about the same time. For example, an eight-armed Avalokiteśvara-'the Bodhisattva of Compassion' - was found at Chaiya, Surat Thani, dated late eighth to early ninth century (Guy 2014: 258-60). The Hindu Brahmanical tradition had made a lasting impact on Sinhalese Buddhism and the sculpting of Avalokiteśvara was open to iconographic influences of Shiva and Durga

11 I thank Dr Piriya Krairiksh for identifying Jambhala (Personal communication, 25 November 2014). Pattaratorn (1997: 36) suggests the posture of relaxation (lalitāsana), but Paul Lavy (Personal communication, 14 July 2011) thinks the pose with one leg crossed in front is royal ease (rajaliläsana). A small bronze, mid-ninth-century Kubera with protruding belly was found in Sathingpra District, Songkhla (Krom 2006: 55).

12 Again, I thank Dr Piriya Krairiksh for this identification (Personal communication, 25 November 2014). The terracotta Jambhala and the Avalokiteśvara in the Colombo museum are illustrated in Reynolds (2017: xv). The late Anuradhapura Avalokiteśvara appeared in Michael Wright's columns but without explanation (Wright 2007a, 2007b). 
(Holt 1991: 79, 82, 112). A Sanskrit work on iconography ascribes to Avalokiteśvara signs of the most important Hindu gods: Shiva, Brahma, Vishnu, Durga, Skanda and Ganesha. By the end of the fourteenth century, the Bodhisattva was assimilated into the Theravada tradition and acknowledged in Ceylon as an important and powerful deity. The deity was known as 'the king of gods' and became associated with monarchical rule and dynastic legitimacy in the Kandyan kingdom. The Avalokiteśvara shrine there had a prominent role in the consecration of its monarchs (Nandana 2002: 56-9). The Jatukham-Ramathep-'the Monarch of the Southern Seas'-impersonates the Avalokiteśvara, the guardian and protector of sovereign space, as the title of one of the pop-history books proudly states (Nan Tapi 2007). Later in its history, the Avalokiteśvara (male), the compassionate saviour, became China Guanyin (female), a deity associated with the sea, which is still very popular in Thailand today (Guy 2014: 62). The merging of Buddhist and Hindu influences and iconography runs deep in the religious history of India, Sri Lanka and Southeast Asia - a reminder that it would be misleading to read the Jatukham-Ramathep as either wholly Buddhist or wholly Hindu.

Early in its history, the Jatukham-Ramathep appeared with a multiheaded serpent hovering over it (Nan Tapi 2007: 26). Sometimes the serpent has had seven heads; sometimes, as in the example from Krabi municipality (Plate 10), it has nine heads. On the base of the Krabi image, the demon Rahu is swallowing the Moon in a mythical representation of a lunar eclipse-an icon shown on many Jatukham-Ramathep amulets.

The Jatukham-Ramathep with the polycephalic hood evokes an event after the Enlightenment when the Buddha endured seven days of storms and heavy rains, and the serpent Mucalinda wound its coils around Shakyamuni to shelter him. The halo-like naga hood protecting a deity is also common in Hindu and Jain as well as Buddhist art (Gaston-Aubert 2010: 117-18). In Thai, this representation of the Buddha is called nak prok ('the protecting naga') and, like the Jambhala and the Avalokiteśvara, it appears early in the history of Buddhist art on the Malay Peninsula. Piriya Krairiksh dates a nak prok found in Krabi to the second half of the sixth century; nak prok votive tablets have also been found in Yala (Piriya 2012: 82-3). Nak prok Buddha images were also common in Khmer art during the Angkor period as the supreme deity in the reign of Jayavarman VII (r. 1181-1218), a devotee of Mahayana Buddhism. A non-Buddhist ancient sculpture of the nak prok genre that resembles the Jatukham-Ramathep is the Nagaraja from the Ajanta cave complex in 
Maharashtra State. In this image, the ruler in regal garb is protected by the hoods of a multiheaded serpent. For many Buddhist devotees, this tangled pedigree of the Jatukham-Ramathep proves to them that the deity is not Buddhist, and the power of the amulet to create wealth is a distortion, even a perversion (rueang wipparit), of the Buddha's teachings (Wright 2007c).

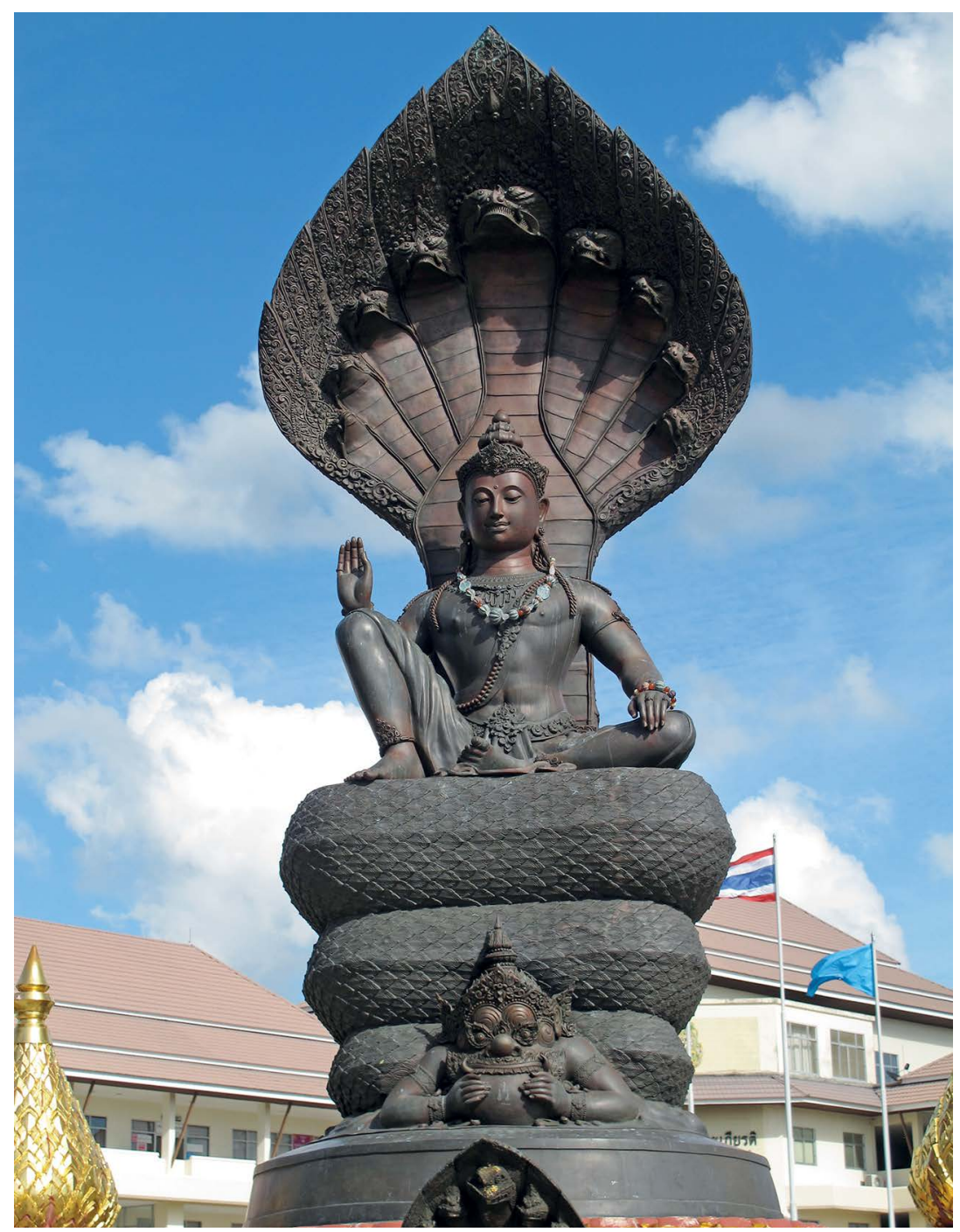

Plate 10 The Jatukham-Ramathep deity, Krabi City Hall

Source: Craig Reynolds. 


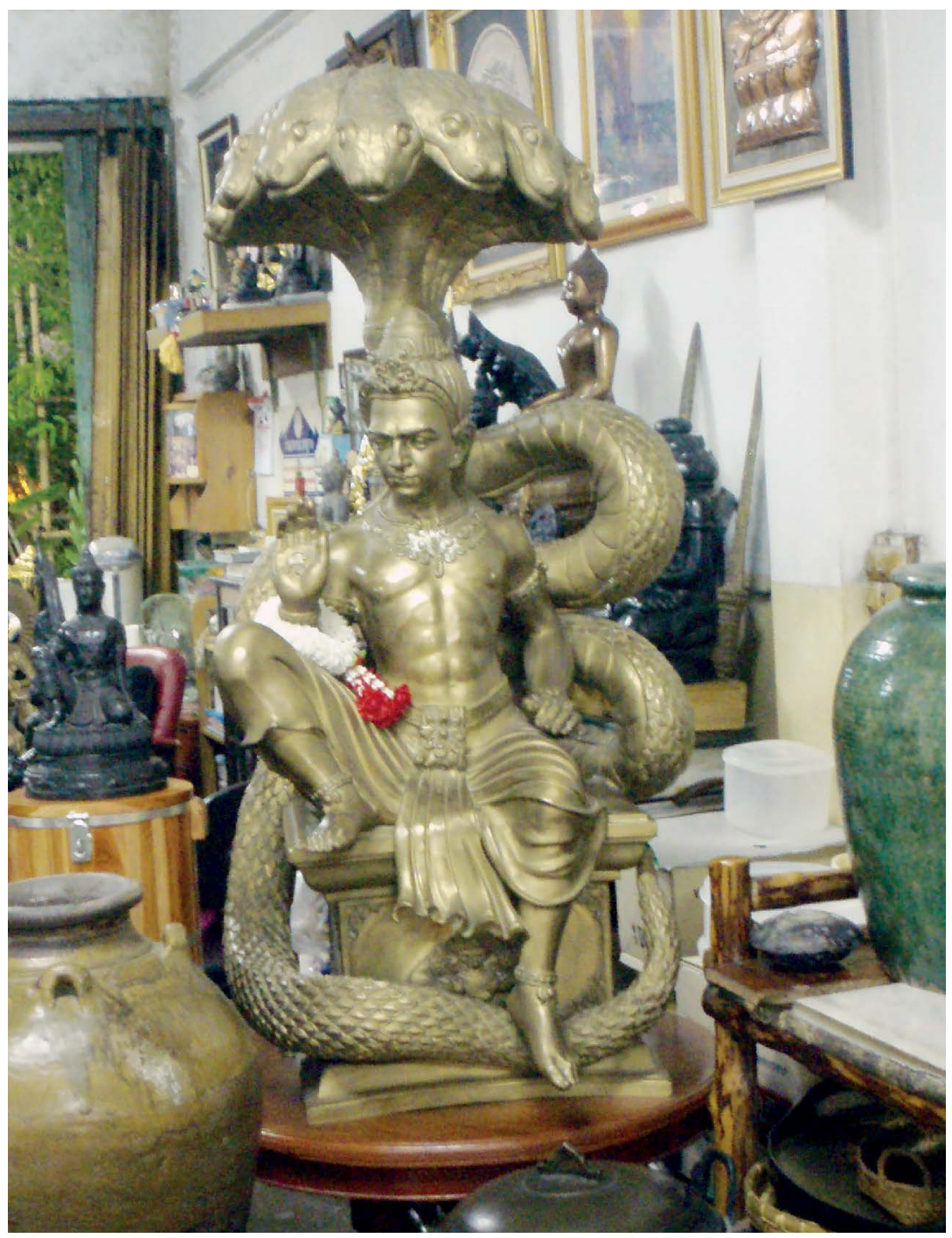

Plate 11 Jatukham-Ramathep image in a Nakhon Si Thammarat restaurant

Source: Craig Reynolds.

At a seafood restaurant in Nakhon, I came across an unusual JatukhamRamathep image of the nak prok type. Jatukham-Ramathep images, including a black one made of heavy timber, looked out from niches in the restaurant's private dining rooms, and a large collection of Buddha images and other objects, sacred and otherwise, was on display in the restaurant lobby. 
There was a bust of King Bhumibol and busts of renowned monk teachers, a few Ganeshas and dancing Shivas, old manual presses for making Chinese noodles and flattening dried squid, some very dead stag coral resting in a waterless tank, a large tortoise shell, an adding machine from a bygone age and two Remington typewriters. I thought I had stepped into a flea market, although the only items on sale were small amulets for THB100 each. The brass image depicted in Plate 11, weighing 130 kilograms, was commissioned by a local Chinese amulet broker, a Sian Phra from Nakhon, and produced in nearby Surat Thani; the deity and its base were cast separately. About 100 copies were made and sold for THB100,000 each (US\$3,125). Rather than coiled up to form a throne, the undulating serpent curls up from below and rises above the body posed in lalitäsana. The seven-headed hood shelters the image; the torso is deeply moulded like the 'six-pack' abdominals of the Jatukham-Ramathep in front of the Nakhon provincial police station. The restaurant proprietor, who assembled his collection at the height of Jatukham-Ramathep fever, explained that the Chinese amulet broker who ordered the image selected a European face. ${ }^{13}$

Images such as this one in the restaurant are what make it difficult to keep up with the morphing Jatukham-Ramathep over the 30 years of its existence. Most amulets are produced by particular monks and monasteries, but the Jatukham-Ramathep seems to have floated free of any copyright, making it even more difficult to track as it popped up all over the country. After a tour of the iron mine at Nam Phi in 2017, I visited Wat Pasak Rerai in Mueang District in Uttaradit Province, where a Jatukham-Ramathep was produced soon after Khun Phan's death. A former soldier-deafened by a mortar blast during his military service and wearing an oversized hearing aid in his left ear-told the story of how the amulet had been manufactured at the monastery in 2007. Prasit Phrommani, who had served as a village headman for 10 years until 2012 and was now an official on the monastery committee, explained that a senior monk in the province had blessed 1,000 amulets, which were then distributed through the monastery's network of devotees, who paid THB1,000 each. The funds were used for new buildings and renovations in the monastery compound. I bought two of the amulets and handed the money to an elderly monk. ${ }^{14}$

13 Restaurant owner, Personal communication, 6 December 2014.

14 Prasit Phrommani, Interview with the author, Wat Pasak Rerai, 10 November 2017. 
Uttaradit is hundreds of kilometres north of Nakhon Si Thammarat, far from the Jatukham-Ramathep's origins and the religious history of the Malay Peninsula. The deity was first called into service to raise funds for the renovation of the city's pillar shrine- the spiritual heart of the townand to restore Nakhon's prosperity and keep it from harm's way. After the military coup of September 2006 and the cremation in February 2007 of the Lion Lawman, devotion to the deity grew into a prosperity cult that was a financial phenomenon as much as a social and religious one. The power of the image, known as the Monarch of the Southern Seas, drew on Nakhon's heritage in community memory as an ancient coastal power to be reckoned with, as a principality that treasured its autonomy and as a religious centre that sent learned monks and Brahmans to the Siamese courts on the central plains. The deity's hold on the local imagination derives from its undecidable origins: the spirit medium it spoke through, the paired deities it embodied that continued to guard the town's great relic, the policeman with magical knowledge and a reputation for taking no prisoners who discovered its modern incarnation and a new horoscope that broke a curse and kickstarted Nakhon's fortunes with a new shrine for the city pillar.

Reflecting on the pedigree of the Jatukham-Ramathep deity, I am reminded of Stanley O'Connor's memorable phrase about 'the sedimentation of long memory' (Wannasarn 2013a: 272). For two millennia, the landscape of the mid south has been transformed by human imagination. Deities were fashioned out of stone and shrines were built for their shelter. What we now call works of art were living gods embodied in terracotta, stone and bronze. As a work of bricolage, the Jatukham-Ramathep deity is just such an object of worship, little different from the ancient sculptures and votive tablets that have been studied by art historians. These devotional objects were conjured from local lore and Southeast Asian, Indic and Lankan religious belief. Promises of quick wealth and good fortune in the auspicious moment of Khun Phan's cremation inflated the JatukhamRamathep's value, and the deity became another instantiation of modern cultural production infused with mythic significance.

In November 2005, just before the Yellow Shirts began their rallies to overthrow the elected government of Police Lieutenant Colonel Thaksin Shinawatra, a special edition of the Jatukham-Ramathep known as Take Back the Nation (run ku chat) was minted and consecrated. In June 2006, the king would have been on the throne for six decades and the Yellow Shirts whipped up enough fury and public unease in the following months 
to precipitate a coup in September of that year aimed at freeing the nation from the grip of Thaksin, the power-mad champion of capitalism, whom the crowds saw as a threat to the monarchy. The Jatukham-Ramathep deity had instructed the rally leader, Sondhi Limthongkul, to commence the demonstrations in February 2006 at the equestrian statue of the fifth Bangkok king. To curb violence, to keep the demonstrators safe from harm and to protect the lives of all patriotic Thais, the JatukhamRamathep deity further instructed - by what means we are not told-that batches of the powdery compound fused in the amulet should be placed underneath the stage's centre and at its four corners to mark out a sacred space. The righteousness of the Yellow Shirt campaign, thus endorsed by the supernatural, would bring certain victory in the political battle that was unfolding. Needless to say, hyping the protective qualities of the Jatukham-Ramathep by such theatrical shenanigans had the intended consequence of inflating the amulet's price (Phirayu 2007: Ch. 4). When Khun Phan passed away in July 2006, a month after the celebrations for the king's fifth-cycle anniversary on the throne, the amulet received its biggest boost in value.

Like Pallas Athena, on which the safety of ancient Athens depended, the Jatukham-Ramathep served as a palladium that protected the leaders of the Yellow Shirts as they issued their demands of the elected government. The deity conjured in the mid south was not just a lucky charm, nor was it merely a volatile commodity that could make a fortune in a single transaction if the purchase was timed correctly. It had begun its modern incarnation as a guardian deity watching over the reliquary at the Wat Mahathat reliquary in Nakhon Si Thammarat, and it could now be assigned the duty of keeping safe a patch of the Earth's surface during a political battle that was shaking the Thai state. 
This text is taken from Power, Protection and Magic in Thailand: The Cosmos of a Southern Policeman, by Craig J. Reynolds, published 2019 by ANU Press, The Australian National University, Canberra, Australia.

doi.org/10.22459/PPMT.2019.05 